\title{
Variasi Spasial Kontribusi dan Struktur Ekonomi Kabupaten/Kota di Provinsi Jawa Tengah Tahun 2013-2017
}

\author{
Andri Kurniawan, Wiedya Nurchasanah, Bias Osean Ali
}

Masuk: 22092019 / Diterima: 13122019 / Dipublikasi: 31122019

(c) 2019 Fakultas Hukum dan IImu Sosial UNDIKSHA dan IGI

\begin{abstract}
The purpose of the study was formulated to analyze the spatial variations in the contribution and structure of the regency/city GRDP in Central Java Province in 2013-2017. Research conducted using quantitative methods by utilizing secondary data related explicitly to GRDP data. The unit of analysis used covers all regencies/ cities in Central Java Province. To represent spatially mapping is done through the use of Geographic Information Systems (GIS). The results showed that there were differences in spatial patterns between the number of contributions and the contribution growth of regency/city to the GRDP of Central Java Province. The difference in spatial patterns is shown by the existence of patterns of relationships that tend to be the opposite. Spatially there are variations in contributions with different patterns between primary, secondary, and tertiary sector groups. The spatial distribution patterns of the primary sector tend to be more evenly distributed compared to the secondary and tertiary sectors. Secondary and tertiary sectors tend to form clusters and corridors. From the comparison of regency/city GRDP structures, some regions develop towards specialization, and some other regions develop towards diversification.
\end{abstract}

\section{Key words: Spatial Variation; Contribution; Economi Structure}

\begin{abstract}
Abstrak Tujuan penelitian dirumuskan untuk menganalisis variasi spasial kontribusi dan struktur PDRB Kabupaten/Kota di Provinsi Jawa Tengah Tahun 2013 -2017. Penelitian yang dilakukan menggunakan metode kuantitatif dengan memanfaatkan data sekunder khususnya terkait data PDRB. Unit analisis yang digunakan meliputi seluruh wilayah kabupaten/kota di Provinsi Jawa Tengah. Untuk merepresentasikan secara spasial dilakukan pemetaan melalui pemanfaatan Sistem Informasi Geografi (SIG). Hasil penelitian menunjukkan terdapat perbedaan pola spasial antara besaran kontribusi dengan pertumbungan kontribusi kabupaten/kota terhadap PDRB Provinsi Jawa Tengah. Perbedaan pola spasial tersebut ditunjukkan dengan adanya pola hubungan yang cenderung berkebalikan. Secara spasial terdapat variasi kontribusi dengan pola yang berbeda antara kelompok sektor primer, sekunder, dan tersier. Pola sebaran spasial sektor primer cenderung lebih merata dibandingkan dengan sektor sekunder dan tersier. Untuk sektor sekunder dan tersier cenderung membentuk klaster maupun koridor. Dari perbandingan struktur PDRB kabupaten/kota, sebagian wilayah berkembang ke arah spesialisasi dan sebagian wilayah lain berkembang ke arah diversifikasi.
\end{abstract}

Kata kunci : Variasi Spasial; Kontribusi; Struktur Ekonomi

\section{Pendahuluan}

Suatu wilayah terus akan mengalami perubahan struktural akibat adanya dinamika intenal maupun karena faktor eksternal. Dalam konteks pembangunan jangka panjang salah satunya dicirikan dengan adanya perubahan struktur ekonomi wilayah (Ghalib, 2005). Provinsi Jawa Tengah

Andri Kurniawan, Wiedya Nurchasanah, Bias Osean Ali Fakultas Geografi, Universitas Gadjah Mada andri.kurniawan@ugm.ac.id merupakan wilayah yang mempunyai dinamika yang cukup tinggi. Salah satu aspek dinamika yang terjadi adalah menyangkut perubahan struktur ekonomi wilayah. Pada tahun 1990 sektor pertanian masih dominan memberikan kontribusi pada PDRB Provinsi Jawa Tengah. Namun demikian pada Tahun 1995, sektor pertanian tidak lagi memberikan kontribusi terbesar. Sektor industri pengolahan telah mulai menggeser dominasi sektor pertanian (Wiguna, 2016). Kondisi di atas telah memberikan gambaran adanya 
dinamika struktur ekonomi wilayah. Selain adanya dinamika struktur ekonomi menurut waktu, di Provinsi Jawa Tengah juga mengalami dinamika spasial struktur ekonomi wilayah menurut kabupaten/kota. Sebagian wilayah kabupaten masih menunjukkan dominasi sektor pertanian, namun kabupaten/kota yang lain sudah mulai bergeser ke sektor industri, perdagangan, dan jasa.

Dinamika struktur ekonomi suatu wilayah dipengaruhi oleh banyak faktor, baik faktor internal maupun eksternal. Potensi sumberdaya alam dan perkembangan infrastruktur sangat berpengaruh terhadap perkembangan sektor ekonomi suatu wilayah. Sumberdaya alam yang melimpah tentu saja akan mendorong berkembangnya sektor primer. Disisi lain pengembangan infrastruktur pada suatu wilayah akan mendorong berkembangnya berbagai kegiatan ekonomi dan pada gilirannya akan mendorong pertumbuhan ekonomi wilayah (Kurniawan, 2018). Namun demikian, peran kualitas sumberdaya manusia dan aspek kelembangaan juga sangat berperan dalam mendorong pertumbuhan sektor ekonomi wilayah. Kondisi wilayah kabupaten/kota di Provinsi Jawa Tengah sangat bervariasi baik menyangkut aspek sumberdaya alam, infrastruktur, sumberdaya manusia, maupun aspek kelembagaan. Perbedaan kondisi tersebut tentu saja akan berdampak pada adanya variasi struktur ekonomi wilayah.

Adanya variasi dan dinamika struktur ekonomi wilayah antar kabupaten/kota di Provinsi Jawa Tengah akan memberikan konsekuensi terhadap kebutuhan kebijakan pembangunan yang lebih tepat. Dominasi struktur ekonomi tertentu akan membutuhkan kebijakan pembangunan yang tertentu pula. Wilayah dengan kontribusi sektor pertanian yang tinggi membutuhkan model kebijakan yang berbeda dengan wilayah yang kontribusi terbesarnya di sektor industri. Penelitianpenelitian sejenis cukup banyak dilakukan, namun lebih terkonsentrasi pada kajian ketimpangan pembangunan ekonomi (Mopangga, 2014; Santosa, 2015), dan perubahan struktur ekonomi dan sektorsektor ekonomi unggulan (Amalia, 2012; Kusreni, 2009; Prawira \& Hamidi, 2013). Penelitian ini menjadi berbeda mengingat yang menjadi fokus kajian adalah tidak hanya terkait dengan struktur ekonomi semata, tetapi juga mengkaji tentang perbedaan secara spasial mengenai kontribusi ekonomi masing-masing wilayah di Provinsi Jawa Tengah melalui pemanfaatan Sistem Informasi Geografi (SIG).

Mendasarkan pertimbangan di atas, tujuan penelitian dirumuskan untuk menganalisis variasi spasial kontribusi dan struktur PDRB Kabupaten/Kota di Provinsi Jawa Tengah Tahun $2013 \quad-2017$. Dipilinnya rentang waktu tersebut sebagai fokus analisis karena dalam penyusunan kebijakan terkait pada umumnya selalu mengacu kepada keadaan terakhir yang dimiliki oleh wilayah bersangkutan. Dinamika struktur ekonomi yang diharapkan terjadi di masa yang akan datang, selalu berkaca dari kondisi ekonomi wilayah saat ini.

\section{Metode}

Penelitian yang dilakukan menggunakan metode kuantitatif dengan memanfaatkan data sekunder berupa Provinsi Jawa Tengah dalam Angka dan Kabupaten/Kota dalam Angka khususnya terkait data PDRB. Unit analisis yang digunakan meliputi seluruh wilayah kabupaten/kota di Provinsi Jawa Tengah. Periode waktu yang digunakan dalam kajian selama 5 (lima) tahun, yaitu mulai Tahun 2013 - 2017. Data 5 (lima) tahun tersebut digunakan untuk menganalisis variasi spasial kontribusi dan struktur PDRB kabupaten/kota di Provinsi Jawa Tengah. Analisis kontribusi meliputi 
besaran dan pertumbuhan kontribusi kabupaten/kota terhadap PDRB Provinsi Jawa Tengah. Struktur PDRB dikaji dan dikelompokkan menurut sektor primer, sekunder, dan tersier. Pembagian tersebut sejalan dengan penelitian (Sahubawa,
Khakim, \& Lasindrang, 2015) yang membahas perubahan struktur ekonomi dalam klasifikasi sistem-teoretis dari perubahan struktural dalam kerangka tigasektor. Adapun pengelompokkan sektor dilakukan seperti terlihat pada Tabel 1 .

Tabel 1. Pengelompokkan Sektor PDRB

\begin{tabular}{lc}
\hline \multicolumn{1}{c}{ Sektor PDRB } & Pengelompokan Sektor \\
\hline Pertanian, Kehutanan dan Perikanan & Sektor Primer \\
Pertambangan dan Penggalian & Sektor Sekunder \\
Industri Pengolahan & \\
Pengadaan Listrik dan Gas & \\
Pengadaan Air, Pengelolaan Sampah, Limbah, dan Daur Ulang & \\
Konstruksi & Sektor Tersier \\
Perdagangan Besar dan Eceran, Reparasi Mobil, dan Sepeda Motor & \\
Transportasi dan Pergudangan & \\
Penyediaan Akomodasi dan Makan Minum & \\
Informasi dan Komunikasi & \\
Jasa Keuangan dan Asuransi & \\
Real Estate & \\
Jasa Perusahaan & \\
Administrasi Pemerintahan, Pertahanan, dan Jaminan Sosial Wajib \\
Jasa Pendidikan \\
Jasa Kesehatan dan Kegiatan Sosial \\
Jasa Lainnya
\end{tabular}

Selanjutnya untuk memudahkan dalam melakukan analisis secara spasial, dilakukan proses klasifikasi terhadap data besaran dan pertumbuhan kontribusi PDRB menurut sektor. Adapun formula yang digunakan untuk menyusun klasifikasi adalah sebagai berikut.

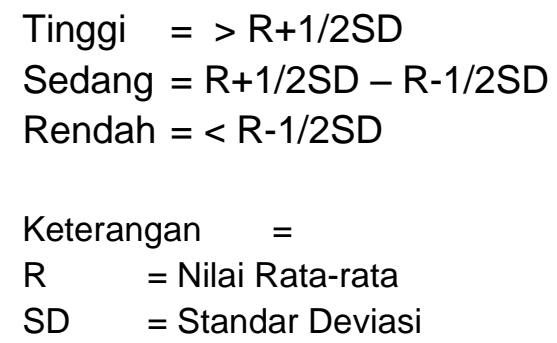

Untuk merepresentasikan secara spasial dilakukan pemetaan melalui pemanfaatan Sistem Informasi Geografi (SIG). Grafik digunakan dalam kajian ini untuk membantu menganalisis perbandingan komposisi atau struktur PDRB antar wilayah kabupaten/kota.

\section{Hasil dan Pembahasan}

Wilayah Provinsi Jawa Tengah merupakan daerah yang struktur ekonominya tidak lagi didominasi oleh sektor primer, namun sudah bergeser ke sektor sekunder. Hal itu sejalan dengan pendapat Todaro (2004) dan Tambunan (2009) dalam Kurniawan (2018) yang memberikan gambaran bahwa negeranegara berkembang telah mengalami perubahan struktural ke arah semakin pentingnya sektor sekunder. Apa yang terjadi di Jawa Tengah dan sesuai pendapat ahli di atas, diperkuat oleh temuan-temuan di wilayah lain di Indonesia dalam hal dominasi struktur ekonomi dan pergeseran yang ada yang sudah tidak menyentuh sektor primer. Misalnya saja di Kota Palu dalam 5 tahun terakhir struktur ekonominya didominasi oleh sektor tersier, disusul oleh sektor sekunder, dan sektor primer (Tenggara, 2015). Di Kota Manado struktur 
ekonominya mirip dengan Palu (Hidayat, 2013). Sementara di Kabupaten Buleleng telah terjadi pergeseran dari sektor primer ke sektor tersier (Wiwekananda \& Utama, 2016). Terjadinya perbedaan struktur ekonomi berikut pergeseran yang terjadi didalamnya sangat tergantung pada karakteristik wilayah yang berbeda-beda.

Di Jawa Tengah pada tahun 2017, kontribusi sektor sekunder terhadap PDRB mencapai $45,47 \%$, jauh melebihi kontribusi sektor primer yang hanya 16,62 $\%$. Tingginya kontribusi sektor sekunder tersebut terutama didukung oleh berkembangnya kegiatan industri pengolahan yang memberikan sumbangan mencapai $34,96 \%$. Sumbangan sektor industri pengolahan terhadap PDRB terus mengalami peningkatan dengan pertumbuhan mencapai 7,01 \%/tahun seperti tersaji dalam Tabel 2. Pertumbuhan tersebut lebih tinggi dari pertumbuhan sumbangan sektor pertanian, kehutanan, dan perikanan yang hanya mencapai 4,82 \%/tahun, namun masih dibawah pertumbuhan beberapa sektor lainnya. Terdapat beberapa sektor di wilayah Provinsi Jawa Tengah yang walaupun sumbangannya relatif kecil namun mempunyai pertumbuhan yang cukup tinggi seperti sektor pertambangan dan penggalian, jasa perusahaan, serta transportasi dan pergudangan.

Tabel 2. Kontribusi dan Pertumbuhan Sektor PDRB

Harga Berlaku Tahun 2013 - 2017 Provinsi Jawa Tengah

\begin{tabular}{lrr}
\hline \multicolumn{1}{c}{ Sektor PDRB } & Kontribusi (\%) & Pertumbuhan (\%/th) \\
\hline Pertanian, Kehutanan dan Perikanan & 14,09 & 4,82 \\
Pertambangan dan Penggalian & 2,53 & 12,50 \\
Industri Pengolahan & 34,96 & 7,01 \\
Pengadaan Listrik dan Gas & 0,10 & 7,68 \\
Pengadaan Air, Pengelolaan Sampah, Limbah, dan & 0,06 & 4,52 \\
Daur Ulang & & \\
Konstruksi & 10,36 & 7,84 \\
Perdagangan Besar dan Eceran, Reparasi Mobil, & 13,60 & 6,61 \\
dan Sepeda Motor & & \\
Transportasi dan Pergudangan & 3,20 & 9,49 \\
Penyediaan Akomodasi dan Makan Minum & 3,20 & 8,80 \\
Informasi dan Komunikasi & 3,30 & 8,32 \\
Jasa Keuangan dan Asuransi & 2,97 & 8,15 \\
Real Estate & 1,67 & 7,97 \\
Jasa Perusahaan & 0,38 & 10,05 \\
Administrasi Pemerintahan, Pertahanan, dan & 2,79 & 5,90 \\
Jaminan Sosial Wajib & & \\
Jasa Pendidikan & 4,38 & 8,79 \\
Jasa Kesehatan dan Kegiatan Sosial & 0,87 & 9,36 \\
Jasa Lainnya & 1,55 & 8,90 \\
Total & 100,00 & 7,16 \\
\hline
\end{tabular}

Sumber: Analisis Data Primer, 2019

Selanjutnya dalam menjelaskan perubahan struktur ekonomi wilayah tidak dapat terlepas dari aspek geografis (spasial) (Constantine \& Khemraj, 2018). Perbedaan kondisi geografis akan mendorong perbedaan potensi dan aksesibiltas sehingga mendorong perkembangan kegiatan ekonomi yang berbeda. Perbedaan perkembangan kegiatan ekonomi akan menentukan perbedaan struktur ekonomi wilayah. PDRB Provinsi Jawa Tengah merupakan gabungan kontribusi PDRB kabupaten/kota. Terdapat beberapa 
wilayah kabupaten/kota yang memberikan kontribusi yang cukup tinggi terhadap PDRB provinsi. Kota Semarang merupakan wilayah yang memberikan kontribusi terbesar dengan sumbangan mencapai lebih dari $13 \%$. Tingginya sumbangan Kota Semarang tidak terlepas perannya sebagai ibu kota provinsi dengan berbagai kegiatan ekonomi yang berkembang, terutama sektor perdagangan dan jasa serta industri pengolahan. Wilayah lain yang juga cukup tinggi memberikan sumbangan adalah Kabupaten Cilacap dan Kudus. Dua wilayah kabupaten ini merupakan basis kawasan industri di Provinsi Jawa Tengah sehingga mampu memberikan kontribusi yang cukup tinggi. Secara spasial, wilayah bagian tengah Provinsi Jawa Tengah mulai dari wilayah selatan hingga utara, merupakan wilayah yang tergolong rendah dalam memberikan kontribusi. Wilayah tersebut meliputi Kabupaten Purworejo, Wonosobo, Banjarnegara, Temanggung, dan Batang. Basis pertanian di wilayah kabupaten-kabupaten tersebut belum mampu mendorong kontribusi secara signifikan. Wilayah kabupaten lain yang termasuk masih rendah kontribusinya adalah Kabupaten Rembang. Disamping itu, terdapat pula beberapa wilayah kota yang masih rendah kontribusinya, yaitu Kota Tegal, Pekalongan, Salatiga, dan Magelang. Skala kota yang masih terbatas menyebabkan kontribusinya juga masih terbatas. Berbeda untuk Kota Surakarta dan Semarang yang mempunyai skala kota yang lebih besar sehingga mampu memberikan kontribusi yang cukup tinggi terhadap PDRB Provinsi Jawa Tengah. Sebaran spasial klasifikasi kontribusi kabupaten/kota terhadap PDRB Provinsi Jawa Tengah tersaji dalam Gambar 1.

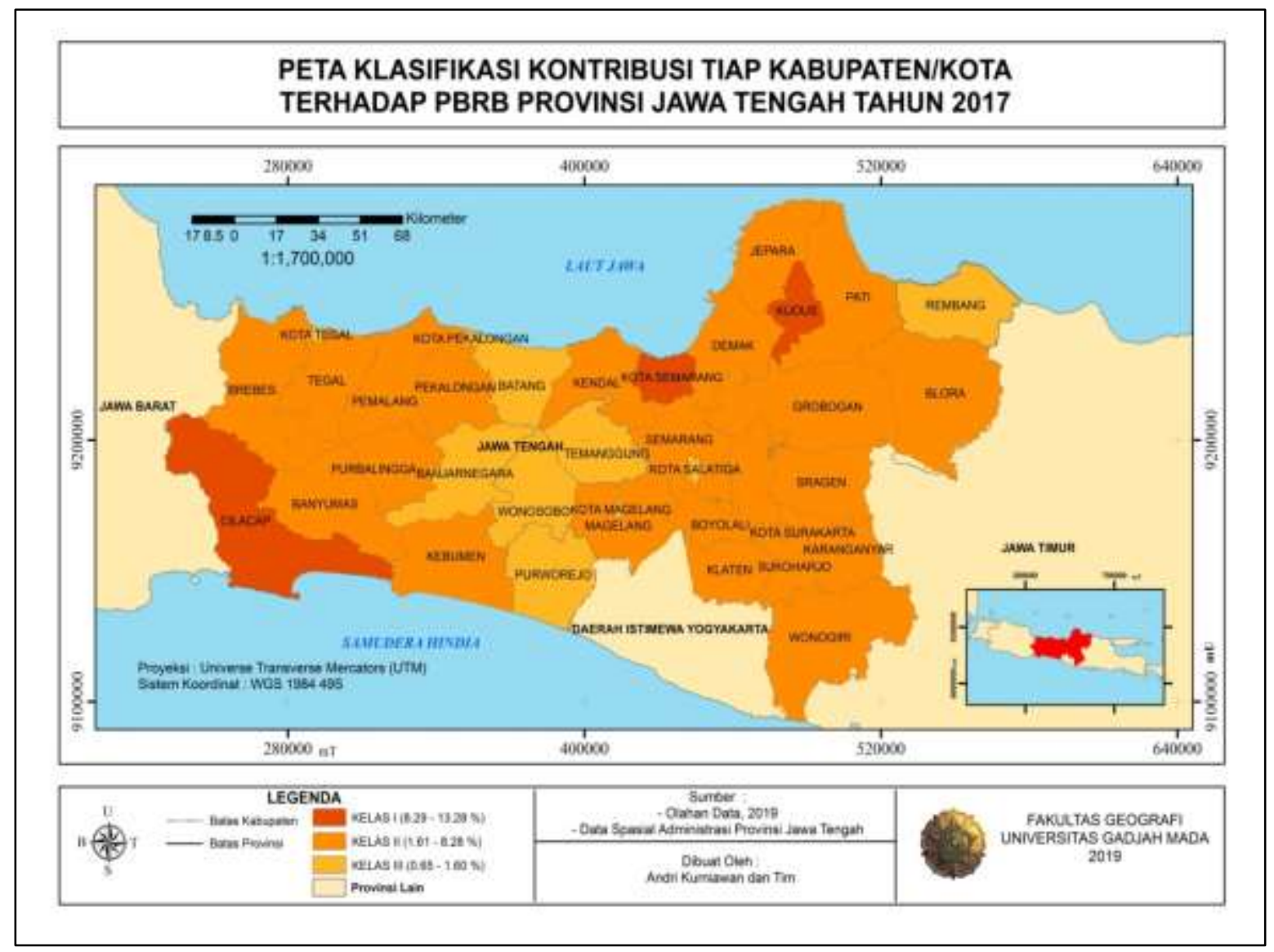

Gambar 1. Peta Klasifikasi Kontribusi Kabupaten/Kota terhadap PDRB Provinsi Jawa Tengah Tahun 2017 
Selain aspek basaran kontribusi, hal lain yang dapat dilihat variasi spasialnya adalah menyangkut pertumbuhan kontribusi. Pertumbuhan kontribusi ini menggambarkan peningkatan PBRB kabupaten/kota sebagai hasil kinerja pembangunan daerah. Dari pengolahan data yang telah dilakukan terhadap data PDRB kabupaten/kota antara tahun 2013 2017 menunjukkan adanya variasi pertumbuhan kontribusi.

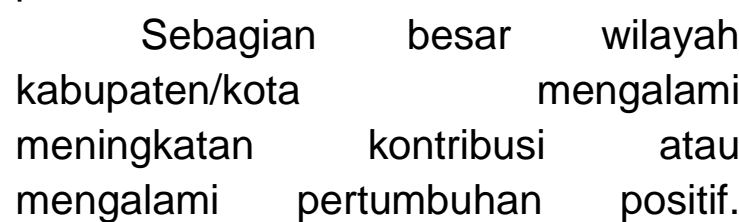
Namun disebagian wilayah lain mengalami penurunan kontribusi atau mengalami pertumbuhan negatif. Kabupaten Blora merupakan wilayah yang mempunyai pertumbuhan kontribusi terbesar. Pertumbuhan kontribusi di Kabupaten Blora didorong oleh peningkatan kontribusi sektor pertambangan dan penggalian serta perkembangan sektor pertanian. Pertumbuhan kontribusi yang tinggi juga terjadi di wilayah bagian timur lainnya, yaitu Kabupaten Sragen dan Boyolali. Di dua wilayah kabupaten tersebut didorong oleh pertumbuhan dibeberapa sektor. Pertumbuhan yang tinggi juga terjadi di wilayah bagian tengah yaitu Kabupaten Banjarnegara. Walaupun mempunyai besaran kontribusi yang relatif rendah, namun mempunyai pertumbuhan kontribusi yang tinggi. Pertumbuhan yang tinggi tersebut didorong oleh berkembangnya sembilan (sektor) di Kabupaten Banjarnegara. Sementara, kondisi yang berkebalikan terjadi di Kabupaten Cilacap. Walau memiliki kontribusi yang besar, namun pertumbuhan kontribusinya mengalami penurunan bahkan merupakan wilayah yang mengalami penurunan kontribusi terbesar di wilayah Provinsi Jawa Tengah. Penurunan kontribusi terjadi karena adanya penurunan kontribusi di sektor pertambangan dan penggalian serta sektor industri pengolahan. Kondisi yang hampir sama dialami oleh Kabupaten Kudus yang kontribusinya mengalami penurunan walaupun besaran kontribusinya masih cukup tinggi. Dengan demikian, terdapat perbedaan pola spasial antara besaran kontribusi dan pertumbungan kontribusi. Perbedaan pola spasial tersebut ditunjukkan dengan adanya pola hubungan yang berkebalikan antara besaran kontribusi dan pertumbuhan kontribusi. Kondisi tersebut menggambarkan pula bahwa di Provinsi Jawa Tengah proses pergeseran struktur ekonomi masih terus terjadi. Hal itu sejalan dengan pendapat (Cardinale \& Scazzieri, 2018) yang menjelaskan teori perubahan struktural yang dicirikan dengan perubahan besaran variabel ekonomi dan pergeseran pertumbuhan sektoral. Namun demikian khusus untuk Kota Semarang, baik besaran kontribusi maupun pertumbuhan kontribusi keduanya mempunyai nilai yang tinggi. Artinya, Kota Semarang mempunyai sumbangan PDRB tinggi dan besaran sumbangan tersebut terus mengalami peningkatan. Hal ini sejalan dengan fungsi Kota Semarang sebagai pusat kegiatan utama di Provinsi Jawa Tengah. Sebaran spasial klasifikasi pertumbuhan kontribusi kabupaten/kota terhadap PDRB Provinsi Jawa Tengah tersaji pada Gambar 2. 


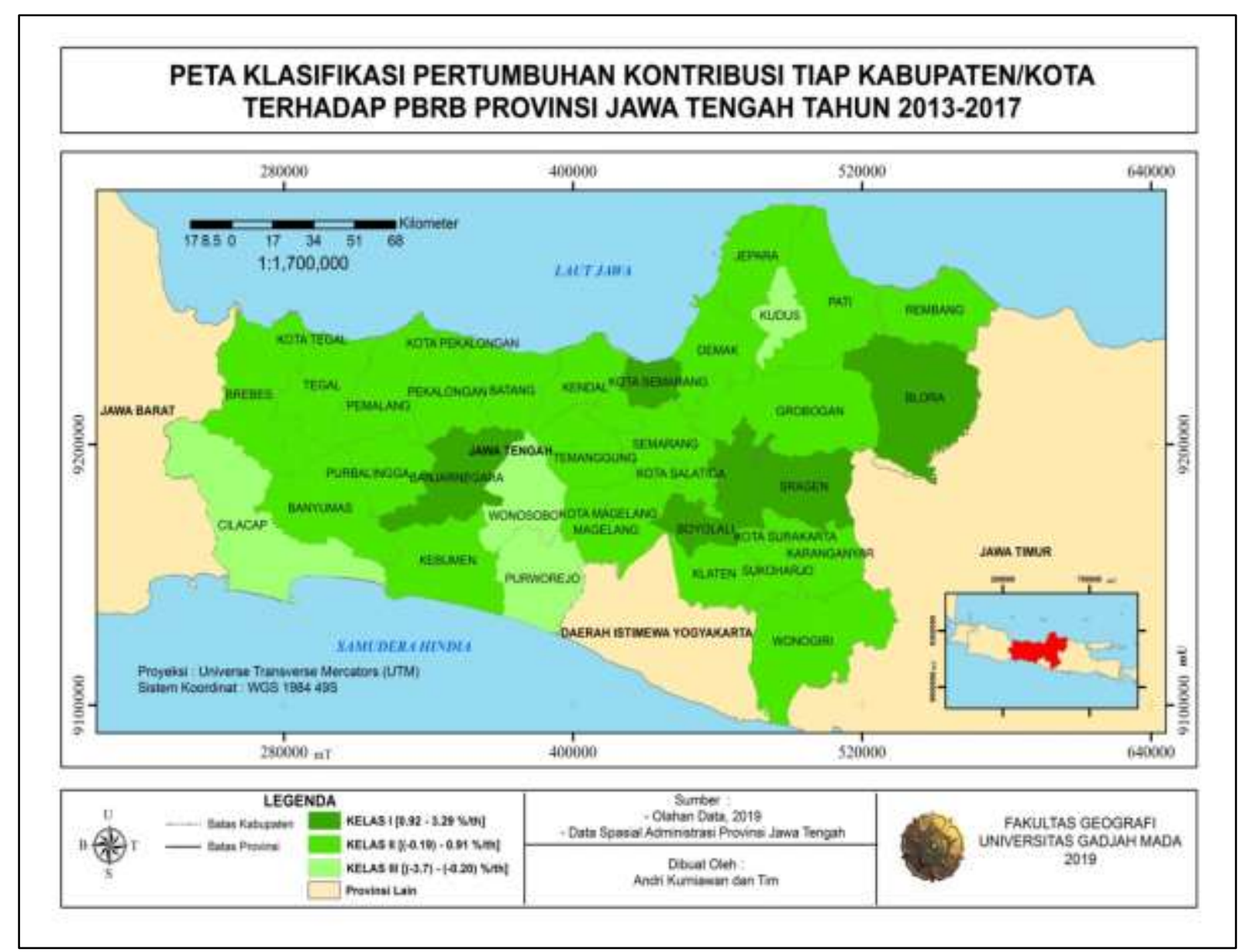

Gambar 2. Peta Klasifikasi Pertumbuhan Kontribusi Kabupaten/Kota terhadap PDRB Provinsi Jawa Tengah Tahun 2013-2017

Selanjutnya jika dilihat secara spasial menurut kelompok sektor primer, sekunder, dan tersier, terdapat variasi spasial dengan pola yang berbeda. Untuk sektor primer, wilayah-wilayah yang mempunyai dominasi sektor primer (kelas tinggi) tersebar baik dibagian barat, tengah, maupun timur. Di wilayah bagian barat, Kabupaten Brebes merupakan wilayah yang masih didominasi sumbangan sektor primer khususnya dari sub sektor pertanian tanaman pangan. Di bagian tengah terdapat beberapa wilayah kabupaten yang masih mengandalkan sektor primer, seperti Kabupaten Kebumen, Banjarnegara, Purbalingga, Wonosobo, dan Pemalang. Kondisi kemampuan lahan yang mendukung untuk pengembangan sektor pertanian sebagai faktor pendorong utama. Di bagian timur terdapat wilayah Kabupaten Rembang, Blora, Grobogan, dan Wonogiri yang masih juga mengandalkan sektor pertanian. Namun demikian, terdapat beberapa wilayah yang sumbangan sektor primernya rendah, terutama di wilayah sepanjang koridor Solo - Semarang dan Solo - Yogyakarta. Adanya transformasi wilayah di sepanjang koridor mengakibatkan sektor pertanian tidak lagi menjadi sektor utama digeger oleh perkembangan sektor perdagangan dan jasa. Sumbangan sektor pertanian yang rendah juga terjadi di wilayah pengembangan industri dan perluasannya, seperti di wilayah Kabupaten Kudus, Jepara, dan Cilacap. Sebaran spasial klasifikasi kontribusi sektor primer kabupaten/kota terhadap PDRB Provinsi Jawa Tengah tersaji dalam Gambar 3. 


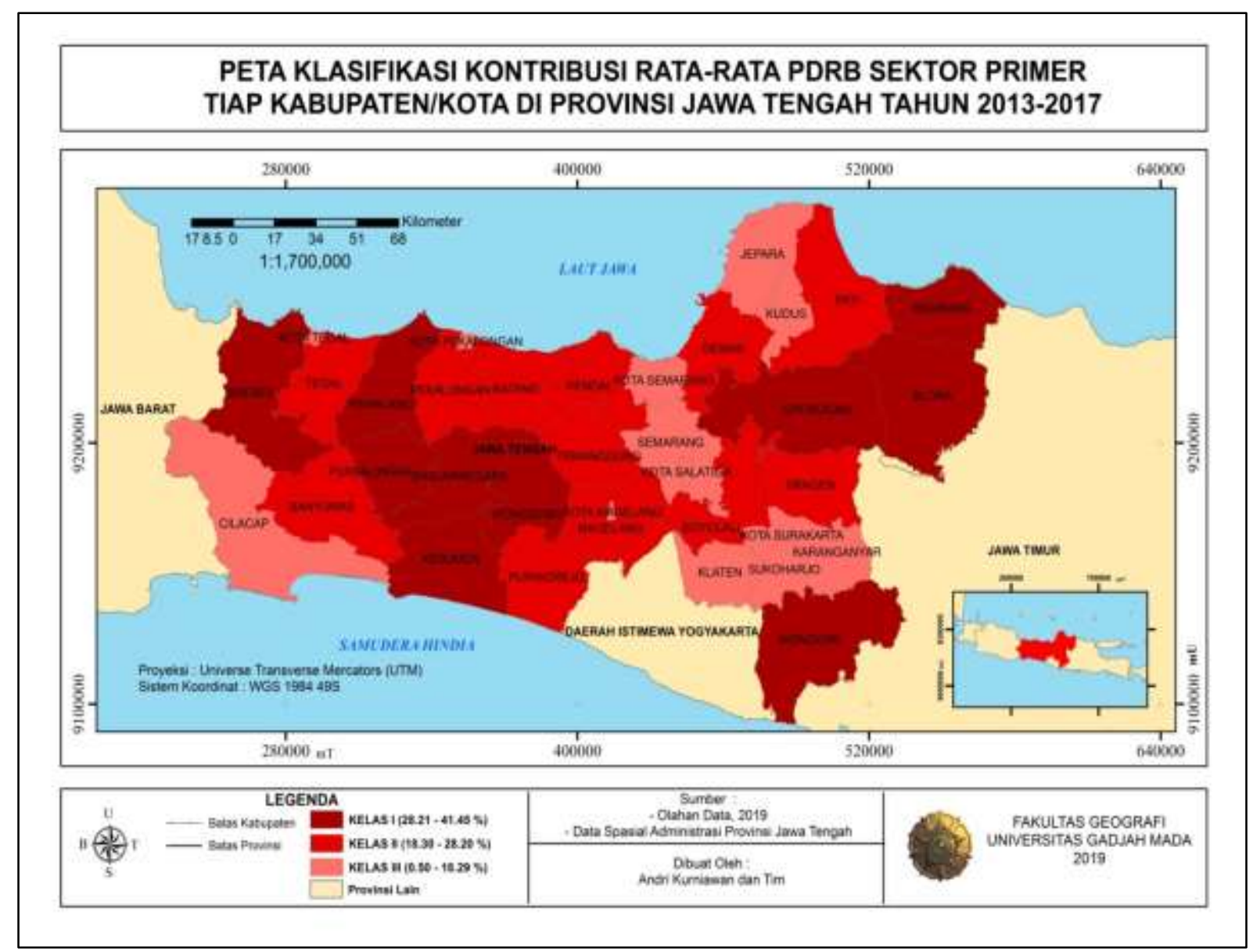

Gambar 3. Peta Klasifikasi Kontribusi PDRB Sektor Primer

Menurut Kabupaten/Kota di Provinsi Jawa Tengah Tahun 2013-2017

Pola sebaran spasial kontribusi sektor primer, berbeda dengan pola sebaran spasial kontribusi sektor sekunder. Secara umum untuk sebaran dominasi kontribusi sektor sekunder, yang terdiri dari sektor industri pengolahan serta pertambangan dan penggalian, menyebar dalam 4 (empat) klaster. Di bagian wilayah barat terdapat Kabupaten Cilacap yang memang merupakan wilayah yang berkembang berbagai industri termasuk industri perminyakan, semen, gula, PLTU, dan lain-lain. Di bagian selatan terdapat klaster Kota Surakarta dan sekitarnya yang merupakan kawasan industri yang cukup besar dengan berbagai jenis industri yang berkembang termasuk industri tekstil. Di bagian utara terdapat 2 (dua) klaster, yaitu di wilayah Kota Semarang dan sekitarnya dan di Kabupaten Kudus. Di wilayah Kota Semarang dan sekitarnya yang meliputi Kota dan Kabupaten Semarang, Salatiga dan Kendal, merupakan kawasan industri yang terus berkembang dengan berbagai jenis industri yang didukung oleh keberadaan Pelabuhan Tanjung Emas. Beberapa lokasi kompleks dan kawasan industri dikembangkan di wilayah ini. Untuk Kabupaten Kudus, keberadaan industri rokok menjadi faktor utama tingginya kontribusi sektor sekunder. Sebaran spasial klasifikasi kontribusi sektor sekunder kabupaten/kota terhadap PDRB Provinsi Jawa Tengah tersaji dalam Gambar 4. 


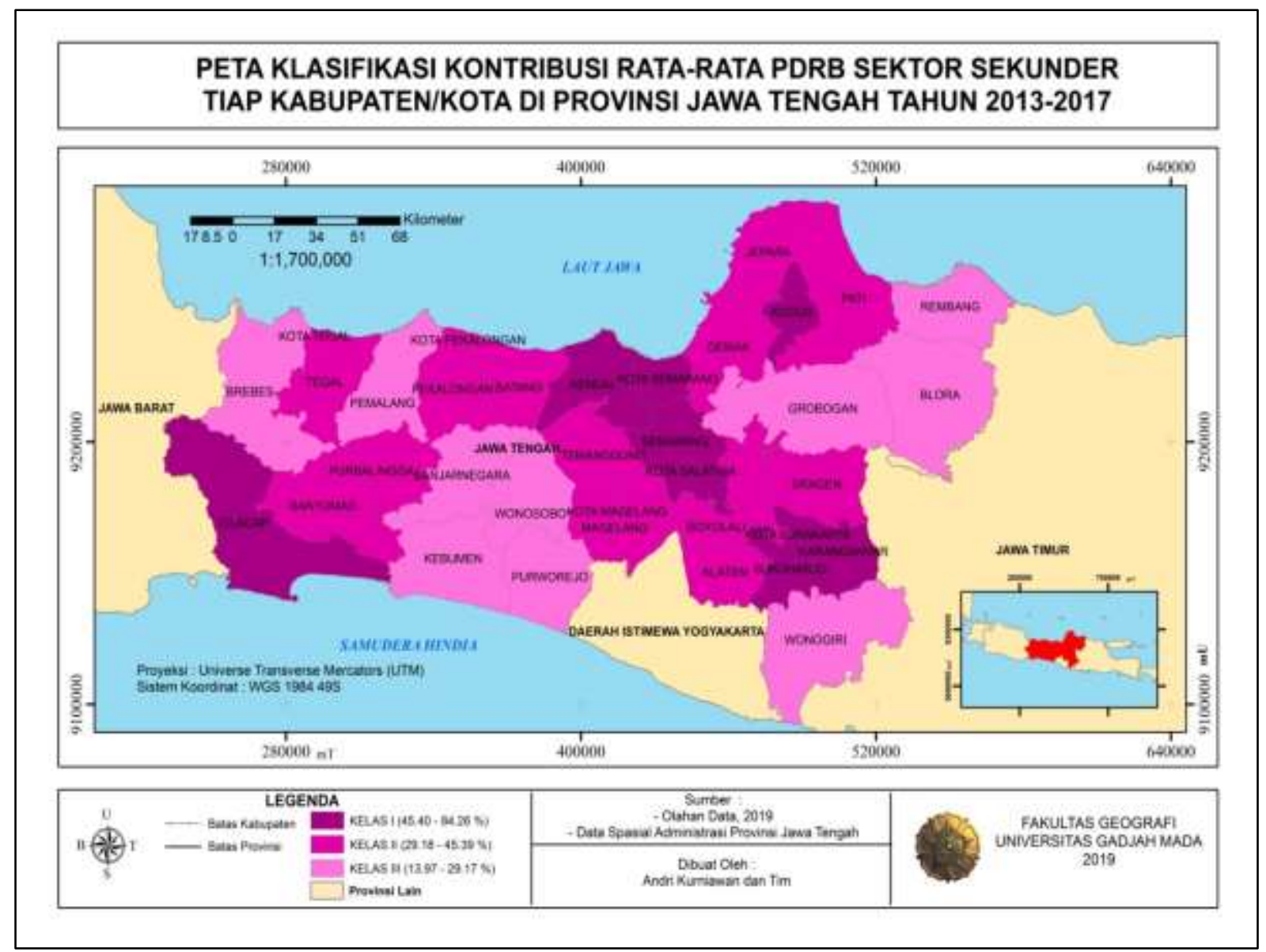

Gambar 4. Peta Klasifikasi Kontribusi PDRB Sektor Sekunder Menurut Kabupaten/Kota di Provinsi Jawa Tengah Tahun 2013-2017

Untuk sebaran kelas kontribusi sektor tersier di wilayah Provinsi Jawa Tengah sejalan dengan perkembangan dan kedudukan kota. Perkembangan sektor tersier merupakan konsekuensi dari berkembangnya suatu kota. Temuan ini sejalan dengan penelitian lainnya yang menyebutkan bahwa salah satu aspek perkembangan kota dicirikan dengan berkembangnya pusat-pusat pelayanan yang pada akhirnya mendorong berkembangnya sektor tersier terutama perdagangan dan jasa (Kairupan, 2013; Rahayu \& Santoso, 2014). Kondisi tersebut menyebabkan semua wilayah yang berstatus kota mempunyai kelas kontribusi sektor tersier yang tinggi.

Selain wilayah yang berstatus kota, terdapat 2 (dua) kabupaten yang mempunyai kelas kontribusi sektor tersier yang tinggi, yaitu Kabupaten Purworejo dan Grobogan. Di wilayah Kabupaten Purworejo, sektor transportasi dan pergudangan serta berbagai sektor jasa telah memberikan sumbangan yang signifikan terhadap PDRB, sedangkan di wilayah Kabupaten Grobogan sumbangan yang signifikan didapatkan dari sektor perdagangan. Yang menarik adalah di beberapa wilayah yang sumbangan sektor industri seperti Kabupaten Cilacap, Kedus, Kendal, Semarang, dan Karanganyar justru belum banyak berkembang kegiatan perdagangan dan jasa sehingga kontribusi sektor tersier masih tergolong rendah. Sebaran spasial klasifikasi kontribusi sektor tersier kabupaten/kota terhadap PDRB Provinsi Jawa Tengah tersaji dalam Gambar 5. 


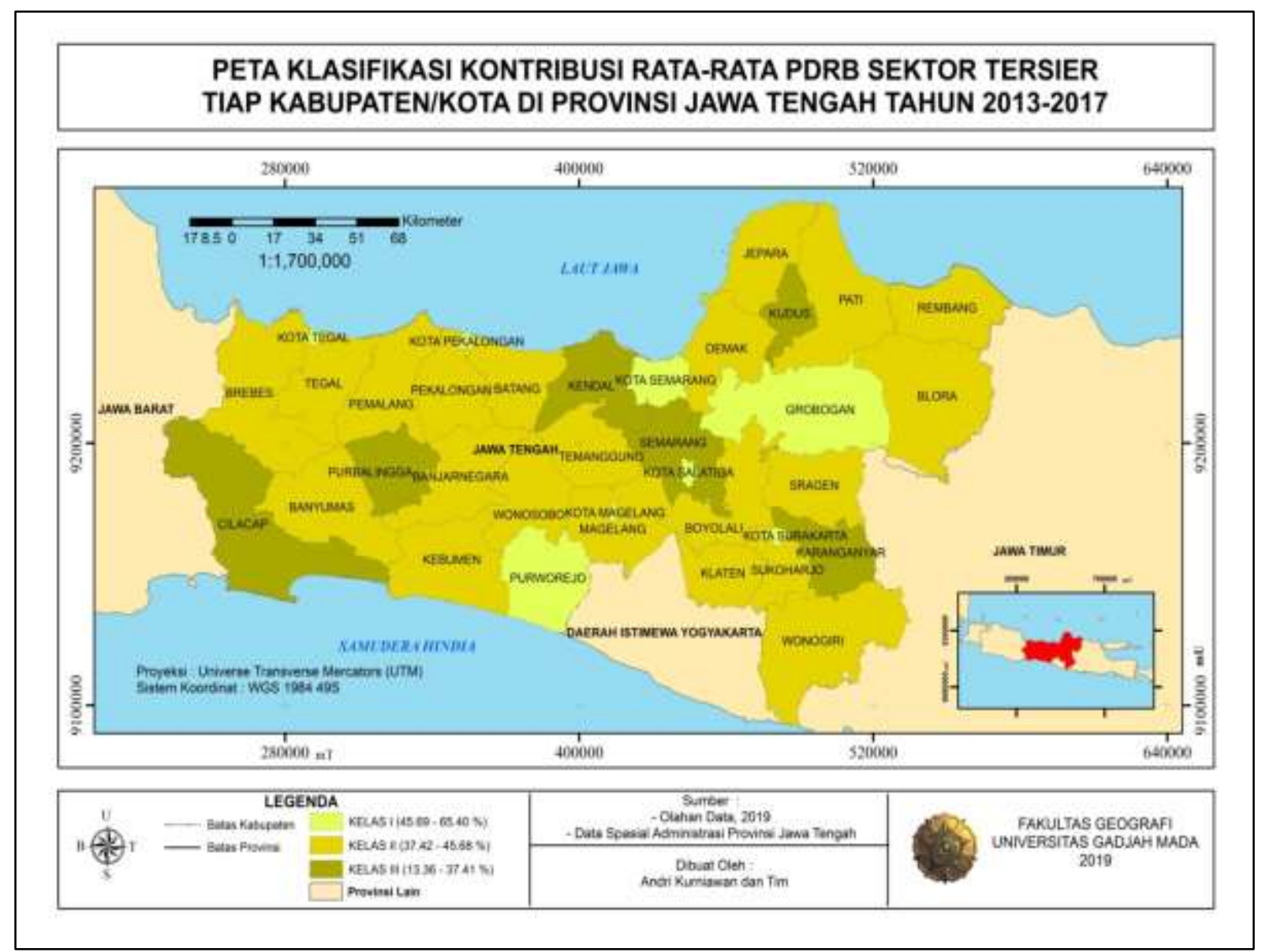

Gambar 5. Peta Klasifikasi Kontribusi PDRB Sektor Tersier

Menurut Kabupaten/Kota di Provinsi Jawa Tengah Tahun 2013-2017

Selanjutnya jika dianalisis terkait struktur ekonomi di wilayah kabupaten/kota di Provinsi Jawa Tengah terlihat adanya perbedaan pola. Di sebagian wilayah terlihat adanya dominasi kelompok sektor tertentu, namun di sebagian wilayah yang lain terlihat lebih merata antar sektor. Dengan kata lain, sebagian wilayah berkembang ke arah spesialisasi dan sebagian wilayah lain berkembang ke arah diversifikasi. Contoh wilayah yang berkembang ke arah spesialisasi adalah Kabupaten Kudus dan Cilacap. Di Kabupaten Kudus, sumbangan sektor sekunder terutama sektor industri pengolahan mencapai lebih $80 \%$. Demikian pula di Kabupaten Cilacap yang sumbangan sektor sekundernya hampir mencapai $70 \%$. Untuk wilayah kota, sebagian kota telah terspesialisasi ke arah dominasi perdagangan dan jasa (sektor tersier) seperti Kota Magelang, Surakarta, Pekalongan, dan Tegal. Secara umum untuk wilayah kabupaten, kecuali Kabupaten Kudus dan Cilacap, lebih berkembang ke arah diversifikasi dengan ciri sumbangan sektor primer, sekunder, dan tersier relatif lebih seimbang. Untuk wilayah kota, khusus untuk Kota Semarang dan Salatiga peran sektor sekunder (industri) masih cukup menonjol disamping peran sektor tersier. Sebaran kontribusi kelompok sektor terhadap PDRB menurut kabupaten/kota di Provinsi Jawa Tengah tahun 2013 - 2017 dapat dilihat pada Gambar 6. 


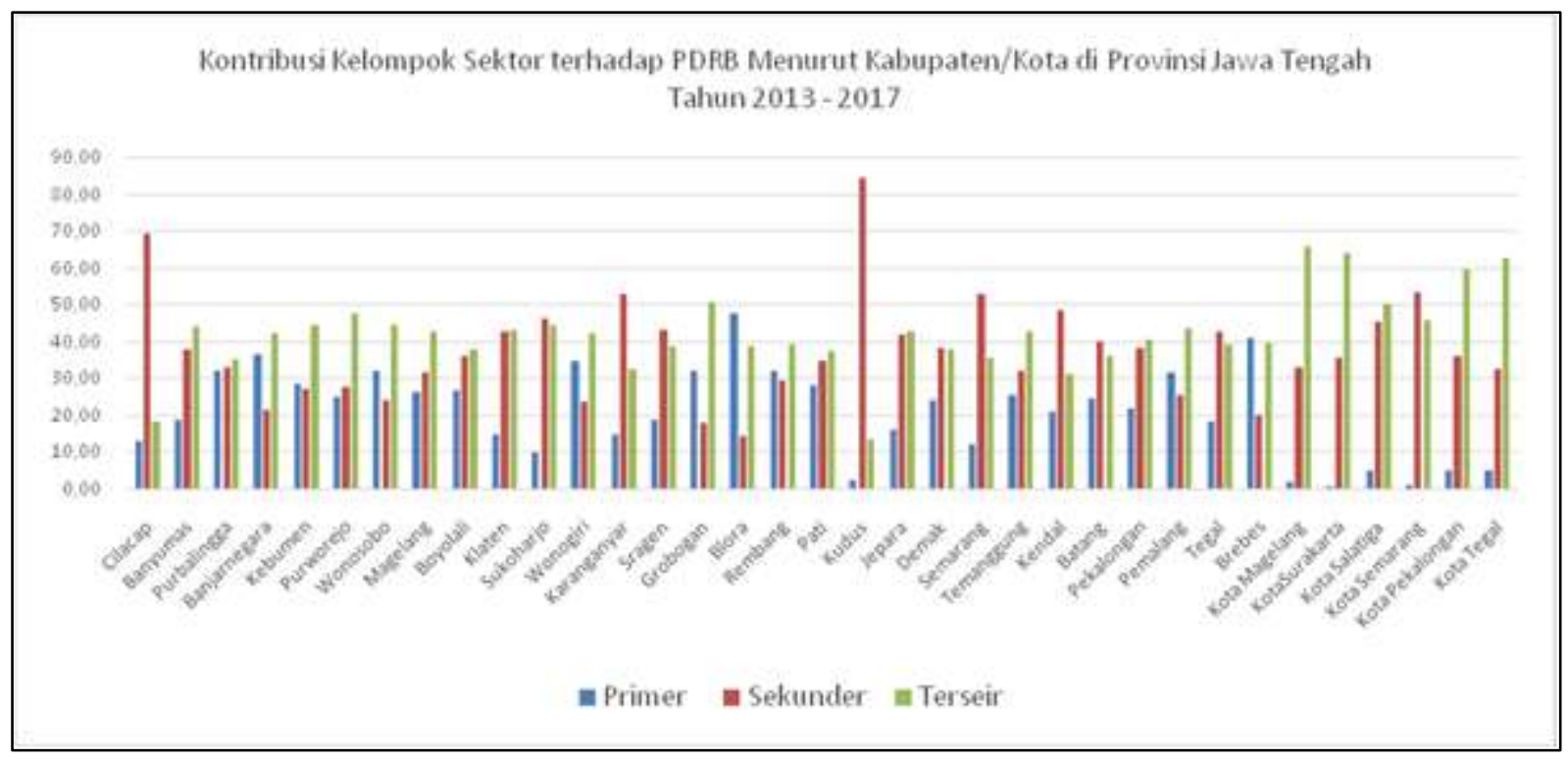

Gambar 6. Kontribusi Kelompok Sektor terhadap PDRB

Menurut Kabupaten/Kota di Provinsi Jawa Tengah Tahun 2013 - 2017

\section{Kesimpulan}

Terdapat perbedaan pola spasial antara besaran kontribusi dengan pertumbungan kontribusi kabupaten/kota terhadap PDRB Provinsi Jawa Tengah. Perbedaan pola spasial tersebut ditunjukkan dengan adanya pola hubungan yang cenderung berkebalikan antara besaran kontribusi dengan pertumbuhan kontribusi. $\mathrm{Hal}$ itu memberikan gambaran bahwa proses pergeseran struktur ekonomi di Provinsi Jawa Tengah terus terjadi dan berpotensi mengalami perubahan struktur secara signifikan. Secara spasial terdapat variasi kontribusi dengan pola yang berbeda antara kelompok sektor primer, sekunder, dan tersier. Pola sebaran spasial sektor primer cenderung lebih merata dibandingkan dengan sektor sekunder dan tersier. Untuk sektor sekunder dan tersier cenderung membentuk klaster maupun koridor. Dari perbandingan struktur PDRB kabupaten/kota, sebagian wilayah berkembang ke arah spesialisasi dan sebagian wilayah lain berkembang ke arah diversifikasi. Spesialisasi terbentuk pada wilayah-wilayah dengan basis sektornya industri dan sebagian sektor perdagangan dan jasa, sedangkan yang kecendunganya ke arah diversifikasi terjadi pada sebagian besar wilayah dengan basis sektor pertanian.

Dari temuan ini, bisa dijadikan sebagai bahan masukan bagi pemerintah dalam memformulasikan kebijakan sesuai karakter wilayah yang mengalami proses pergeseran struktur ekonomi. Wilayah dengan kontribusi sektor primer membutuhkan model kebijakan yang berbeda dengan wilayah yang kontribusi terbesarnya di sektor sekunder dan tersier.

\section{Daftar Pustaka}

Amalia, F. (2012). Penentuan Sektor Unggulan Perekonomian Wilayah Kabupaten Bone Bolango Dengan Pendekatan Sektor Pembentuk PDRB. Etikonomi, 11(2), 101-111.

Cardinale, I., \& Scazzieri, R. (2018). Explaining structural change: actions and transformations. Structural Change and Economic Dynamics, 51, $1-12$.

Constantine, C., \& Khemraj, T. (2018). Geography, Economic Structures and Institutions: A Synthesis. Structural Change and Economic Dynamics, 51, 13-21. 
Ghalib, R. (2005). Ekonomi Regional. Bandung: Bandung Pustaka Ramadhan.

Hidayat, J. (2013). Analisis Struktur Perekonomian Di Kota Manado. Jurnal EMBA, 1(3), 930-938.

Kairupan, S. P. (2013). Produk Domestik Regional Bruto (Pdrb), Inflasi dan Belanja Daerah Pengaruhnya Terhadap Kesempatan Kerja di Sulawesi Utara Tahun 2000-2012. Jurnal EMBA, 1(4), 2206-2216.

Kurniawan, A. (2018). Hubungan antara Tingkat Perkembangan Wilayah dengan Daya Saing Infrastruktur di Provinsi Jawa Tengah. Universitas Gadjah Mada.

Kusreni, S. (2009). Pengaruh Perubahan Struktur Ekonomi Terhadap Spesialisasi Sektoral Dan Wilayah Serta Struktur Penyerapan Tenaga Kerja Sektoral Untuk Daerah Perkotaan Di Jawa Timur. Jurnal Ekonomi Dan Bisnis Airlangga, 19(1), $1-10$.

Mopangga, H. (2014). Analisis Ketimpangan Pembangunan dan Pertumbuhan Ekonomi di Provinsi Gorontalo. Trikonomika Journal, 10(1), 40-51.

Prawira, Y., \& Hamidi, W. (2013). Transformasi Struktur Ekonomi Kabupaten Siak Tahun 2001-2010. Jurnal Ekonomi, 20(1), 1-10.

Rahayu, E., \& Santoso, E. B. (2014). Penentuan Pusat-Pusat Pertumbuhan Dalam Pengembangan Wilayah di Kabupaten Gunungkidul. Jurnal Teknik Pomits, 3(2), 290-295.

Sahubawa, L., Khakim, N., \& Lasindrang, M. (2015). Kajian Sebaran Potensi Ekonomi Sumber Daya Kelautan di Pantai Selatan Daerah Istimewa Yogyakarta Sebagai Upaya Percepatan Investasi. Jurnal Teknosains, 4(2), 101-120.

Santosa, S. H. (2015). Disparitas Pertumbuhan Ekonomi dan Pembangunan Ekonomi Wilayah di Satuan Wilayah Pembangunan IV Propinsi Jawa Timur. Media Trend, 10(2), 116-128.

Tenggara, A. P. (2015). Analisis Struktur Ekonomi Dan Identifikasi SektorSektor Unggulan Di Kota Palu. Jurnal
Katalogis, 3(7), 163-174.

Wiguna, D. P. (2016). Sebaran Disparitas Antar Daerah di Kabupaten Banyumas. Jurnal Ekonomi Dan Studi Pembangunan, 8(2), 41-53.

Wiwekananda, I. B. P., \& Utama, I. M. S. (2016). Transformasi Struktur Ekonomi dan Sektor Unggulan di Kabupaten Buleleng Periode 20082013. Jurnal Ekonomi Kuantitatif Terapan, 9(1), 37-45. 